\title{
INNOVATION STUDY PROGRAM TEACHING FOR PRE-SCHOOLS
}

\section{Jarmila HONZÍKOVÁ - Pavla SOVOVÁ}

\begin{abstract}
The following theoretical study summarises the existing data on the realisation of combined studies and suggests a solution for practical application of newly-emerged methods for verifying readiness of the students studying combined studies of early-childhood teaching at the Faculty of Pedagogy within the technical education discipline at the West Bohemian University in Pilsen.
\end{abstract}

Key words: studies of early-childhood teaching, combined studies, West Bohemian University in Pilsen.

\section{INOVACE STUDIJNÍHO PROGRAMU UČITELSTVÍ PRO MATEŘSKÉ ŠKOLY}

Resumé: Předložená teoretická studie shrnuje dosavadní poznatky z realizace kombinované formy studia a předkládá řešení pro konkrétní využití nově vzniklé metodiky ověřování profesní připravenosti studentů kombinovaného studia oboru Učitelství pro mateřské školy na Západočeské univerzitě v Plzni, Fakultě pedagogické v oboru pracovní výchova.

Klíčová slova: studium Učitelství pro MŠ, kombinované studium, Západočeská univerzita v Plzni.

\section{1 Úvod}

$\mathrm{Na}$ mateřských školách $\mathrm{v}$ západočeském regionu učí řada nekvalifikovaných učitelů, kteří si musí dle legislativních nároků doplnit kvalifikaci do roku 2014. Dále je i řada učitelek, které si chtějí svou kvalifikaci prohloubit o vysokoškolský stupeň vzdělání. Je vhodné nabídnout možnost, jak by tyto skupiny mohly svého cíle dosáhnout. Dle zkušenosti FPE ZČU (ale i dle zkušenosti jiných pedagogických fakult) počet zájemců o kombinovanou formu studia narůstá. Uchazeči jsou často limitováni nevhodnou dopravní dostupností, omezenými časovými možnostmi, pracovními povinnostmi ap. Kvalitativní analýzou subjektivního vnímání průběhu studia $\mathrm{v}$ kombinované formě se zabývaly Lovasová, Brabcová. [2] Přestože byl tento výzkum původně orientován na doktorské studijní programy, lze generalizovaně u studentů všech studijních programů v kombinované formě, identifikovat specifickou formu zátěže vyplývající ze schopnosti adaptability jejich sociálních systémů. Tato míra adaptability vychází především $\mathrm{z}$ vývojově aktuálních hodnotových preferencí studentových rodinných a pracovních struktur. Úspěšnost ve studiu v kombinované formě tudíž nezáleží pouze na intelektových schopnostech a volním úsilí studenta, ale hluboce se na ní podílí i celková emocionální stabilita jedince ovlivněná vstupy zdánlivě se studiem nesouvisejícími. Vytvořením podmínek na straně vysoké školy může být u studentů kombinované formy tato specifická zátěž redukována a tím jim i reálně usnadněn př́stup k získávání požadované kvalifikace.

Optimalizace podmínek je na FPE ZČU v Plzni řešena vytvořením kombinované formy studia Učitelství pro mateřské školy, která koncepčně zahrnuje maximální využivání systému Courseware a vývoj metodiky ověřování profesní prripravenosti.

\section{Vysokoškolské studium Učitelství pro mateřské školy}

Obor Učitelství pro mateřské školy je na fakultách v České republice trríletý, je realizován bud'to jako forma denního studia či forma kombinovaného studia. Studijní programy vesměs deklarují v souladu s evropskými kompetencemi předškolního vzdělávání vyváženou intenzivní teoretickou i praktickou př́ípravu. $\mathrm{V}$ poslední době dochází $\mathrm{k}$ přesunu prŕipravy učitelek mateřských škol na terciární úroveň, čímž se přiblížilo obsahově i metodicky vzdělávání pro předškolní a primární stupeň. Od 90. let vznikají první modely společné vysokoškolské př́ípravy pedagoga pro předškolní vzdělávání. Český přístup profiloval učitelku pro mateřské školy jako odborníka na péči a vzdělávání dětí ve věku 3 až 6 let v mateřských školách. Vysokoškolské studium učitelství pro mateřské školy bylo postaveno jako bakalářské. V současné době je odbornost učitele MŠ koncipována jako odbornost oborová, oborově 
didaktická a odbornost pedagogickopsychologická. Vymezování odbornosti ve struktuře studijních programů jednotlivých fakult zaznamenává pouze zanedbatelné rozdíly, které jsou charakteristické pouze rozšířením některých disciplín a jejich časovou dotací. [4]

Stejný vývoj zaznamenalo studium preprimární pedagogiky i na Slovensku.

\section{Studium Učitelství pro MŠ na Západočeské univerzitě v Plzni}

Západočeská univerzita zajišt'uje v současné době výuku pro více než 20000 studentů. Fakulta pedagogická, která působí na poli vzdělávání budoucích učitelů od roku 1948, má odborný i materiální potenciál nejen pro pregraduální, ale i pro postgraduální vzdělávání učitelů. V rámci celoživotního vzdělávání realizuje nespočet kurzů poskytujících kvalifikaci nebo rozšiřujících kvalifikaci. Pedagogičtí pracovníci mají zkušenosti jak z kvalifikačních studií, tak i z krátkodobých kurzů.

Studium Učitelství pro mateřské školy bylo na FPE ZČU akreditováno ve studijním programu B 7531- Předškolní a mimoškolní pedagogika a bylo zahájeno $\mathrm{v}$ akademickém roce 1998/99 v prezenční formě. Velmi často však studenti využívali tzv. upravenou formu studia, kterou umožňoval studijní řád ZČU do konce akademického roku 2011/12. Případní zájemci $\mathrm{z}$ řad pedagogů po̊sobících v MŠ měli tedy jistou formou zpřístupněno vysokoškolské vzdělání. V záŕí 2012 byla zahájena kombinovaná forma studia. Garantem studia je katedra pedagogiky, i když na samotné výuce se podílí řada kateder a široký tým akademických pracovníků. [6]

\section{Inovace výuky studia Učitelství pro MŠ}

Vytvoření a zahájení výše zmíněné kombinované formy studia je hlavním cílem inovace výuky Učitelství pro MŠ. Očekává se, že se zároveň i posílí interakce a spolupráce edukační reality mateřských škol s akademickým prostředím a zvýší se úroveň vysokoškolské výuky teoretickou reflexí praxe především cestou rozvoje profesních kompetencí akademických pracovníků. [6] Inovativnost spočívá v důrazu na progresivní metody elektronického vzdělávání a na jeho optimální kombinaci s již osvědčenými formami kontaktní výuky.

\section{Systém Courseware a jeho využití v kombinované formě studia Učitelství pro mateřské školy}

Na Západočeské univerzitě v Plzni tvoří základ prezenčního i kombinovaného studia elektronické podpory Courseware. Cílem tohoto programu je shromáždit na jedno místo veškeré elektronické informace a materiály používané $\mathrm{v}$ rámci výuky předmětů na ZČU, jako pomoc při každodenní práci studentů a vyučujících. Celý systém je dostatečně obsáhlý a ovládáním dostatečně jednoduchý, aby vyhovoval potřebám všech fakult univerzity. Jeho významnou předností je maximální integrace a vytěžování informací zadávaných do IS/STAG a dalších informačních systémů ZČU. Courseware je integrované do univerzitního portálu provozovaného v technologii IBM WebSphere Portal, což umožňuje prezentování výukových materiálů jednotnou formou, v jednotné struktuře. Díky tomu mohou studenti jednoduchým a transparentním způsobem přistupovat $\mathrm{k}$ informacím o předmětech při studiu nebo v okamžiku tvorby individuálních studijních plánů, a vyučujícím je usnadněna tvorba a zpřístupnění těchto informací.

Systém Courseware má tyto výhody:

- snadná editace stránek bez technických znalostí,

- napojení na IS/STAG a tím pádem automatická aktualizace informací (rozvrhy, anotace, personální obsazení, ...),

- bezpečné řízení př́istupu $\mathrm{k}$ informacím bez nutnosti zrrizovat studentům další hesla apod.,

- další funkce, které na běžných www stránkách nejsou k dispozici, nebo se obtížně realizují (diskuse, elektronické odevzdávání semestrálních prací,...).

- možnost nabízet dokumenty formou odkazu pouze vybraným skupinám studentů - jen pro studenty předmětu, všem studentům univerzity, všem lidem na internetu.

Courseware jsou v současné době využívány ve většině předmětů studijního plánu oboru Učitelství pro MŠ. Napřr. oddělení technické výchovy katedry matematiky, fyziky a technické výchovy se podílí na kombinovaném studiu Učitelství pro MŠ podílí pěti předměty a všechny jsou již v courseware. Jedná se o předměty zaměřené na pracovní činnosti a kreativní tvoření, didaktiku pracovní výchovy a praxi, jakož i na didaktickou technologii, kde se studenti učí pracovat s nejmodernější didaktickou 
technikou. Systematické využití studijních opor v systém v Courseware modernizuje výuku a posiluje kontakt mezi studenty a pedagogy. Elektronický prostor prrispívá ke vzájemné spolupráci. [1]

\section{Metodika ověřování profesní připravenosti} [5]

V současné době je na základě akčního pedagogického výzkumu vytvářena metodika na uznání výsledků předchozího formálního i neformálního vzdělání (Metodika ověřování profesní připravenosti, dále MOPP).

Pro tvorbu MOPP byly navrženy tyto postupy: 1. Určit, co se bude ověřovat - kritéria profesionality (souhrn způsobilostí absolventa), zvolit způsob, jak se budou způsobilosti ověřovat (určit a zvolit metody ověřování)

2. Vybrat vhodné části z profilu absolventa pro uznání předchozího vzdělávání a jasně formulovat kritéria úspěšnosti.

3. Pilotně prověřit navržený systém, zkušenosti evaluovat. Využít odbornou supervizi.

Zároveň je tvorba Metodiky pro uznávání předchozího vzdělávání (formálního i neformálního) v kontextu současné situace ve školství (absence Standardu profesních kompetencí učitele) velmi náročná. Tvorba metodiky je pojata jako akční pedagogický výzkum. Odpovědný tým se zabývá následujícími aktivitami:

- Komparace u nás publikovaných konceptů profesních kompetencí učitele (včetně popisů Profilu absolventa oboru Učitelství pro MŠ, jak je formulován na jednotlivých pedagogických fakultách, popř. standardů odborných sdružení jako Kritické myšlení, Step by Step)

- Inovace stávajícího Profilu absolventa oboru na FPE ZČU-na základě poznatků $\mathrm{z}$ výše uvedené analýzy.

- Mapování metod diagnostikování úrovně pedagogických kompetencí (resp. znalostí, dovedností, schopností a postojů).

- Analýza všech typů kurzů, které jsou nabízeny $\mathrm{v}$ rámci celoživotního vzdělávání nekvalifikovaným učitelům MŠ ve vzdělávacích institucích Plzeňského kraje za účelem zvýšení či doplnění jejich kvalifikace. Popis a klasifikace těchto kurzů $\mathrm{z}$ hlediska obsahu, rozsahu a výstupů (popis získaných způsobilostí).

- Vytvoření systému zkoušek a oveřování profesionální připravenosti. Volba vhodných nástrojů a metod (např. využití portfolia, posouzení expertní hospitace, videonahrávky pedagogické práce doplněnou teoretickou reflexí v určitém rozsahu apod.). Důležitými kritérii bude přehlednost, reálná dostupnost (možnost připravit se) dané zkoušky. Zásadní charakteristikou musí být prokazatelná kvalitativní věrohodnost a transparentnost prověření profesionality.

- Experimentální ověření metodiky a její představení na odborném semináŕi.

- Č́stečné využití Metodiky u studentů kombinované formy studia jako východiska individualizace studia (ve spolupráci s hlavním koordinátorem, metodikem a akademickými pracovníky, kteří se podílejí na výuce).

Výstupem těchto aktivit bude:

- Metodika pro ověrování profesionální připravenosti - systém zkoušek a diagnostických aktivit, které věrohodně prověří potřebnou úroveň pedagogických kompetencí.

- Odborný text na téma kvalitativního vnímání a diagnostiky úrovně pedagogických kompetencí.

Doposud byly navrženy následující možnosti využití této metodiky:

- Zefektivnění a individualizace studijní cesty v kombinované formě studia (Student nemusí být vzděláván $\mathrm{v}$ tom, co již ovládá. Napřr. student kombinované formy studia působí již řadu let $\mathrm{v}$ oboru a mohl absolvovat různé semináře a kurzy DVPP, včetně kurzů CŽV, které nabízejí VŠ, popř. také uzavřené předměty ze studia na jiné VŠ)

- Úprava studijní cesty i v prezenční formě studia např. pro absolventa SPgŠ, oboru Učitelství pro 1. st. apod.

- Metodika napomůže smysluplně upravit plán kombinované formy studia, může být využita k úpravě přijímacího řízení.

- V souvislosti s tvorbou MOPP se nabízí př́ležitost přezkoumat, přehodnotit či upravit také konvenční zkoušku/ověření profesní připravenosti - kvalifikační zkoušku - státní závěrečné bakalářské zkoušky. 
Základ pro tvorbu metodiky tvoří specifikace dosažených způsobilostí a jejich evaluace. Pro představu uvedeme způsobilosti a jejich ověřování $\mathrm{u}$ předmětů $\mathrm{z}$ oboru technického vzdělávání.

\section{Pracovní činnosti}

V rámci inovace byly pro pracovní činnosti a jejich jednotlivé předměty specifikovány předpokládané způsobilosti a jejich evaluace. Tyto způsobilosti budou tvořit podklad pro tvorbu metodiky uznávání formálního a neformálního vzdělávání právě u studentů kombinovaného studia učitelství pro MŠ. [5]

Katedra Matematiky, fyziky a technické výchovy - technická výchova

Senzomotorické činnosti jsou nedílnou součástí našeho života a učení se jim je důležité pro vzdělávání a rozvíjení celé osobnosti. Osvojování senzomotorické dovednosti, např́íklad pracovní, není jen izolovaným problémem mechanického drilu, ale značně závisí na intelektu a motivaci. [3] Během osvojování senzomotorických dovedností dochází k určitým změnám v psychických a fyziologických procesech: Senzomotorické dovednosti a činnosti se děti učí dvěma způsoby. Jedním z těchto způsobů je živelný postup napodobování a neustálého opakování. Tím druhým je postup, kde děti učíme, aby přemýšlely, analyzovaly a předvídaly své chyby, využívaly získaných znalostí a vědomostí, kontrolovaly nejen výsledky své práce, ale i jejich průběh.

Z výše uvedeného vyplývá i důležitost zařazení předmětů technické výchovy do studijního programu studentů předškolní pedagogiky, nebot' ti se zde naučí nejen samotným pracovním dovednostem a teoretickým poznatkům o materiálech, které by měl pedagog ovládat, ale zároveň i postupům, jak vést děti k získávání těchto dovedností.

Za důležité lze považovat zařazení předmětu didaktické technologie, kde se studenti učí vyhledávat a zpracovávat informace potřebné pro svoji práci pomocí nejnovější didaktické techniky.

\begin{tabular}{|c|c|}
\hline $\begin{array}{l}\text { MŚMA - Materiály } \\
\text { a pracovní techniky }\end{array}$ & $\begin{array}{l}\text { Celkově: } \quad \text { Demonstrace } \\
\text { dovedností při semináři, } \\
\text { průběžná } \\
\text { vzorové } \\
\text { s dokumentací, výrobky } \\
\text { zkouška. }\end{array}$ \\
\hline $\begin{array}{l}\text { Student } \begin{array}{r}\text { zvládne } \\
\text { teoretické }\end{array} \\
\text { základní } \\
\text { poznatky o materiálech, } \\
\text { nástrojích a nářadí. }\end{array}$ & $\begin{array}{lr}\begin{array}{l}\text { Evaluace } \\
\text { vzorových }\end{array} & \text { demonstrace } \\
\text { a jejírobku } & \text { dokumentace, } \\
\text { která } & \text { obsahuje } \\
\text { vysvětlení } & \text { postupu } \\
\text { a s popis } & \text { poznatků } \\
\text { o materiálech } & \\
\end{array}$ \\
\hline
\end{tabular}

\begin{tabular}{|c|c|}
\hline & $\begin{array}{l}\text { a nástrojích, ústní } \\
\text { zkouška z oboru teorie. }\end{array}$ \\
\hline $\begin{array}{lr}\begin{array}{l}\text { Dokáže sám dle návodu } \\
\text { či fantazie }\end{array} & \begin{array}{r}\text { zhotovit } \\
\text { rúzných }\end{array} \\
\text { matebky z } & \begin{array}{r}\text { kreativnélů, } \\
\text { obměňovat }\end{array} \\
\text { postupy, } & \begin{array}{r}\text { pracovní } \\
\text { naplánovat } \\
\text { skupinovou }\end{array} \\
\begin{array}{l}\text { Dokáčci. } \\
\text { kooperativní }\end{array} & \text { uplatnit } \\
\text { dovednosti. } & \\
\begin{array}{l}\text { Zdokonaluje } \\
\text { manipulační }\end{array} & \text { činnosti, } \\
\text { rozvíjí vkus. } & \end{array}$ & $\begin{array}{l}\text { Demonstrace dovedností } \\
\text { při semináři, průběžná } \\
\text { evaluace dovedností. } \\
\text { Evaluace didaktické } \\
\text { stránky postupu. }\end{array}$ \\
\hline 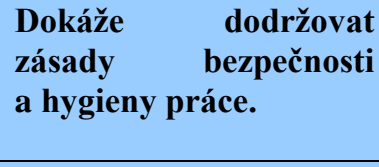 & 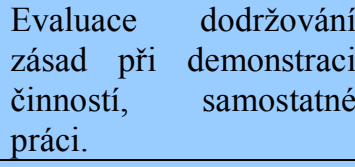 \\
\hline $\begin{array}{l}\text { MŠTD1 - Tvořivá dílna } \\
1\end{array}$ & $\begin{array}{lr}\text { Celkově: } & \text { Průběžná } \\
\text { evaluace, } & \text { individuální } \\
\text { prezentace } & \text { finálního } \\
\text { výrobku na semináři. }\end{array}$ \\
\hline $\begin{array}{l}\text { Student zvládne využití } \\
\text { různých materiálů } \\
\text { a technik pro výrobu } \\
\text { didaktických pomůcek } \\
\text { a hraček pro předškolní } \\
\text { zařízení. } \\
\text { komunikativních } \\
\text { a psychosociálních } \\
\text { kompetencí v tvořivé } \\
\text { práci. }\end{array}$ & $\begin{array}{l}\text { Průběžná evaluace } \\
\text { pracovních dovedností. } \\
\text { Evaluace } \\
\text { komunikativních } \\
\text { dovedností. }\end{array}$ \\
\hline $\begin{array}{lr}\text { Zvládne } & \text { výrobu loutek, } \\
\text { maňásků } & \text { pro jednu } \\
\text { ruku, } & \text { prstových } \\
\text { maňásků a } & \text { hraček } \\
\text { různými } & \text { technikami } \\
\text { s využitím } & \text { různých } \\
\text { materiálů, } & \text { umí } \\
\text { navrhnout jejich využití } \\
\text { ve vztahu ke spontánní } \\
\text { hře. }\end{array}$ & $\begin{array}{lr}\text { Evaluace } & \text { individuální } \\
\text { prezentace } & \text { finálního } \\
\text { výrobku. } & \end{array}$ \\
\hline $\begin{array}{l}\text { MŠTD2 - Tvořivá dílna } \\
2\end{array}$ & $\begin{array}{lr}\text { Celkově: } & \text { Průběžná } \\
\text { evaluace, } & \text { individuální } \\
\text { prezentace } & \text { finálního } \\
\text { výrobku na semináři. }\end{array}$ \\
\hline $\begin{array}{l}\text { Student zvládne využití } \\
\text { různých materiálů } \\
\text { a technik pro výrobu } \\
\text { dekorativních } \\
\text { předmětů. }\end{array}$ & Průběžná evaluace. \\
\hline $\begin{array}{l}\text { Zvládne } r \text { výrobu } \\
\text { a přípravu divadelních } \\
\text { scén v podmínkách } \\
\text { tř́ídy. Zvládne výzdobu }\end{array}$ & $\begin{array}{lr}\text { Evaluace } & \text { individuální } \\
\text { prezentace } & \text { finálního } \\
\text { výrobku. } & \end{array}$ \\
\hline
\end{tabular}




\begin{tabular}{|c|c|}
\hline 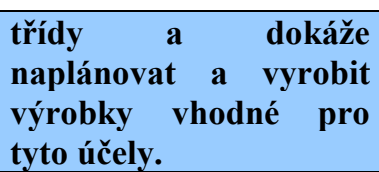 & \\
\hline $\begin{array}{l}\text { Dokáže naplánovat } \\
\text { podíl dětí na výzdobě } \\
\text { předškolního zařízení, } \\
\text { uplatnit poznané lidové } \\
\text { zvyky a tradice. }\end{array}$ & $\begin{array}{l}\text { Rozbor ukázky } \\
\text { plánování činnosti. }\end{array}$ \\
\hline $\begin{array}{l}\text { Umí zdůvodnit význam } \\
\text { dekorací pro rozvoj } \\
\text { smyslů dítěte a podíl } \\
\text { dětí na spoluvytváření } \\
\text { zdravého, podnětného } \\
\text { a bezpečného prostředí. }\end{array}$ & $\begin{array}{l}\text { Evaluace } \\
\text { komunikativních } \\
\text { a sociálních schopností. }\end{array}$ \\
\hline $\begin{array}{l}\text { MŠDI - Didaktika } \\
\text { pracovních činností a } \\
\text { praxe }\end{array}$ & $\begin{array}{lr}\text { Celkově: } & \text { Průběžná } \\
\text { evaluace, na základě } \\
\text { plánování a projektování } \\
\text { pracovních } & \text { činností } \\
\text { vypracuje } & \text { seminární } \\
\text { práci. }\end{array}$ \\
\hline 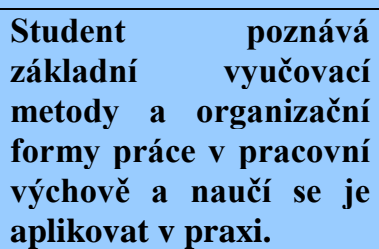 & $\begin{array}{l}\text { Průběžná evaluace práce } \\
\text { s metodami, } \\
\text { organizování práce. }\end{array}$ \\
\hline 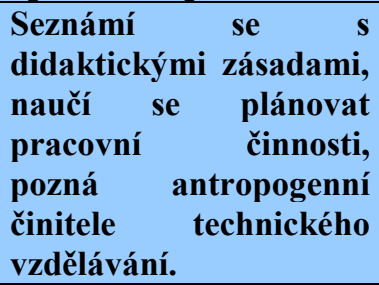 & $\begin{array}{l}\text { Hodnocení dodržování } \\
\text { didaktických zásad při } \\
\text { plánování pracovních } \\
\text { činností. }\end{array}$ \\
\hline 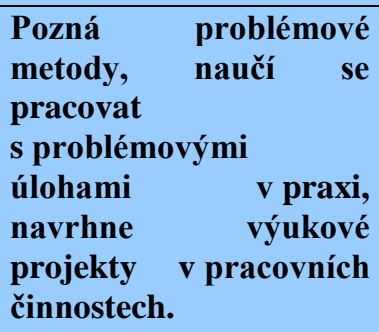 & $\begin{array}{l}\text { Evaluace prezentace } \\
\text { vlastního výukového } \\
\text { projektu } \\
\text { s problémovými } \\
\text { úlohami. }\end{array}$ \\
\hline $\begin{array}{lrr}\text { Dokáže } & \text { při } & \text { plánování } \\
\text { činností } & \text { uplatňovat } \\
\text { zásady } & \text { a } & \text { principy } \\
\text { technického vzdělávání. }\end{array}$ & $\begin{array}{l}\text { Zapracuje didaktické } \\
\text { zásady a principy do } \\
\text { seminární práce. }\end{array}$ \\
\hline $\begin{array}{l}\text { Dokáže získané znalosti } \\
\text { a dovednosti uplatnit } \\
\text { v praxi. }\end{array}$ & $\begin{array}{lr}\text { Rozbor pedagogické } \\
\text { praxe } \\
\text { pracovních } \quad \text { hlediska } \\
\text { hodnocení } \quad \text { uplatnostíní } \\
\text { pedagogických } \\
\text { kompetencí. }\end{array}$ \\
\hline $\begin{array}{ll}\text { DITMŠ } & \text { Didaktická } \\
\text { technologie } & \end{array}$ & $\begin{array}{l}\text { Celkově: } \text { Demonstrace } \\
\text { dovedností při cvičení. }\end{array}$ \\
\hline
\end{tabular}

\begin{tabular}{|c|c|}
\hline & $\begin{array}{l}\text { Seminární práce a její } \\
\text { individuální prezentace } \\
\text { na semináři. }\end{array}$ \\
\hline $\begin{array}{l}\text { Student je schopen } \\
\text { využívat a pracovat s } \\
\text { moderní didaktickou } \\
\text { technikou a za její } \\
\text { pomoci } \\
\text { studijní podpory próret } \\
\text { vlastní výuku. }\end{array}$ & $\begin{array}{l}\text { Průběžná evaluace práce } \\
\text { s didaktickou technikou. }\end{array}$ \\
\hline $\begin{array}{l}\text { Student umí vyhledávat } \\
\text { a zpracovávat } \\
\text { informace a je schopen } \\
\text { realizovat jejich } \\
\text { distribuci v } \\
\text { prezentovatelné formě. } \\
\text { Student při své práci } \\
\text { postupuje systematicky } \\
\text { a kreativně, kombinuje } \\
\text { různé vstupy (media) a } \\
\text { postupy. }\end{array}$ & $\begin{array}{l}\text { Hodnocení vypracování } \\
\text { a prezentace vlastních } \\
\text { studijních opor. }\end{array}$ \\
\hline
\end{tabular}

Tyto způsobilosti jsou zároveň postaveny tak, aby zasahovaly do všech oblastí z RP:

Dítě a společnost - MŠTD2, MŠTDI, DITMŠ

Dítě a svět - MŠMA, MŠDI

Dítě a tělo - MŠMA, MŠTD1

Dítě a jeho psychika - MŠMA, MŠDI, MŠTD1, MŠTD2

Dítě a společnost - MŠTD2, MŠDI, DITMŠ

\section{Pilotní ověření MOPP}

Pilotní ověření bude realizováno s prvními studenty kombinované formy studia.

Při př́ipravě Metodiky uznávání formálního a neformálního vzdělávání studentů kombinovaného studia $\mathrm{z}$ oboru pracovních činností byl vybrán předmět Materiály a pracovní techniky (MŠMA), následně pak Tvořivá dílna I a Tvořivá dílna II. Při předmětu MŠMA student předloží sadu vzorových výrobků, která bude doplněna o popis poznatků o materiálech, nástrojích a postupech. Bude hodnoceno provedení jednotlivých výrobků a to jak po didaktické stránce, tak po stránce využití různých technologií za dodržování zásad bezpečnosti při demonstraci. Zároveň bude provedena evaluace komunikativních a sociálních schopností.

\section{Závěr}

Každá inovace má ovšem i svá rizika. Zde lze za rizika považovat nedostatek informovanosti potenciálních zájemců, nedostatečná motivace účastníků $\mathrm{k}$ volbě studia, obava cílové skupiny z používání ICT nástrojů, nedostatečné 
dovednosti s těmito nástroji, obava z nezvládnutí některých disciplín (např.HV,TV), neschopnost překonat překážky v adaptační fázi studia, riziko nadměrné administrace a problém financování.

Tvorba Metodiky ověřování profesní připravenosti se ukázala jako náročný proces, přesto první zkušenosti potvrzují smysluplnost tohoto směřování.

\section{Literatura}

[1] HONZÍKOVÁ, Jarmila. Studium učitelství pro $M S ̌$ jako dialog praxe s teorii. In: Chráska, M; Klement, M; Serafín, Č; Havelka, M. Monografie z mezinárodní konference Trendy ve vzdělávání - Olomouc : UPOL, 2012. - 4. s. ISBN 978-80-86768-36-6.

[2] LOVASOVÁ, Vladimíra; BRABCOVÁ, Dana. Reflexe studentů kombinované formy doktorského studijního programu psychologie. In Sborník príspěvkì z PhD existence. Olomouc: Univerzita Palackého, 2011. s. 190-196. ISBN: 978-80-244-2858-1

[3] PROTEAU, Luc; MARTENIUK, Ronald G.; LÉVESQUE, Line. A sensorimotor basis for motor learning: Evidence indicating specificity of practice. The Quarterly Journal of Experimental Psychology, 1992, 44.3: 557-575.

[4] SPILKOVÁ, Vladimíra; HEJLOVÁ, Helena. Př́íprava učitelů pro primární a preprimární vzdělávání v Česku a na Slovensku Vývoj po roce 1989 a perspektivy. Praha: UK, PF, 2010. ISBN 978-80-7290-486-0.
[5] SOVOVÁ, Pavla a kol. Metodika ověrováni profesni prípravenosti. [druhá verze pracovních podkladů pro výstup projektu „Studium učitelství pro MŠ jako dialog praxe s teorii“", reg.č. 1.07/2.2.00/18.0022]

[6] Západočeská univerzita v Plzni. Obsahová část projektu Studium učitelství pro MŠ jako dialog praxe s teorií. Projekt č. 1.07/2.2.00/18.0022, poskytovatel MS̆MT OPVK Oblast podpory 2.2. Termín řešení 3/2011 - 2/2014, hlavní řešitel Mgr.Pavla Sovová, Ph.D.

Doc. PaedDr. Jarmila Honzíková, Ph.D.

Katedra matematiky, fyziky a technické výchovy,

Fakulta pedagogická, ZČU v Plzni

Klatovská 51

30000 Plzeň, ČR

Tel: +420 377636500

E-mail: jhonziko@kmt.zcu.cz

Www pracoviště: http://www.zcu.cz/fpe/kmt

Mgr. Pavla Sovová, Ph.D.

Katedra pedagogiky,

Fakulta pedagogická, ZČU v Plzni

Chodské nám 1

30000 Plzeň, ČR

Tel: +420 377636341

E-mail: psovova@kpg.zcu.cz

Www pracoviště: http://www.zcu.cz/fpe/kpg 